\title{
Increasing early crops of unprotected tomatoes (Lycopersicon esculentum Mill.) with naphthoxyacetic acid applied on whole plants
}

\author{
KRYSTYNA GÓRECKA and LESZEK S. JANKIEWICZ \\ Research Institute of Vegetable Crops, 96-100 Skierniewice, Poland
}

(Received: December 12, 1987)

\begin{abstract}
A parthenocarpy-inducing preparation, Betokson, containing beta-naphthoxyacetic acid (NOA) as an active ingredient, was applied by spraying whole plants. As one of the controls, dipping the trusses in NOA solution was used according to a currently recommended technique. NOA applied by each of these treatment increased the very early yield (first 4 pickings) by 4-11 times in cv. Venture and 3-4 times in cv. New Yorker in comparison with the untreated controls. Treating the whole plant increased the very early yield more than did dipping the trusses. The early yield (first 8 pickings) was also increased in cv. Venture by NOA applied by both methods. Treatments with NOA decreased, however, the late yield. This decline was more marked with the higher NOA concentration and when the whole-plant-spray was applied. Gibberellic acid $\left(\mathrm{GA}_{3}\right)$ applied alone as a whole-plant-spray at a concentration of $25 \mathrm{mg} \cdot \mathrm{dm}^{-3}$, did not increase the very early yield but in combination with NOA, increased the early yield in cv. New Yorker. $\mathrm{GA}_{3}$ alone, or in combination with NOA, applied as a spray on the whole plant caused marked chlorosis of the leaves and marked decline of the total yield.
\end{abstract}

\section{INTRODUCTION}

In Poland, and in several other countries with rather cool springs, the fecundation of the earliest trusses of outdoor-grown tomatoes is usually insufficient. The same phenomenon occurs frequently in greenhouses due to poor light conditions. This causes scarce early fruiting. To overcome this, preparations contatining growth regulators like beta-naphthoxyacetic acid (NOA), 4-chlorophenoxyacetic acid (4-CPA) and others, are often used (Kępkowa, 1968; Lipari, 1982). In Poland, Betokson - a preparation containing NOA as an active ingredient - was introduced into practice as early as the nineteen fifties (Kępkowa, 1959).

It has been used up to now only by spraying particular trusses or by dipping them in the solution. Precautions were issued against using Betokson 
on the whole plant, because it was shown in protected cultivation to often be harmful to apical parts of the plant (Kępkowa 1968; Lipari, 1982).

This experiments is a continuation of an earlier one (Górecka and Jankiewicz, 1978). Its aim was to check if Betokson could be applied in unprotected cultivation by spraying the whole plant instead of dipping or spraying only trusses as has been recommended up to now.

The method of spraying the whole tomato plant makes it possible to use the preparation in large scale production. In addition, gibberellic acid $\left(\mathrm{GA}_{3}\right)$ alone, or in combination with NOA, was tested for improving parthenocarpic fruit set. Gibberellins combined with NOA stimulate parthenocarpic fruit development in the greenhouse when used as trusses spray (Strack 1986; Strack and $\mathrm{Stah} 1,1986$ ). Some authors, however, obtained reduced fruit weight with $\mathrm{GA}_{3}$ treatment (Abad and Guardiola, 1986).

\section{MATERIAL AND METHODS}

The experiment was carried out at the Research Institute of Vegetable Crops in Skierniewice in 1978 in an open field with a podsolic soil composed of a layer of clay-sand situated on a medium clay. The soil received $25 \mathrm{t} / \mathrm{ha}$ of compost in the autumn and $84 \mathrm{~kg} \mathrm{~N}$ as ammonium-nitrate limestone, $88 \mathrm{~kg}$

\section{Table 1}

Dates of agricultural treatments (1978)

\begin{tabular}{|c|c|}
\hline Date & Treatment \\
\hline 03.23 and 04.12 & sowing and preplanting, respectively \\
\hline 05.15 & treating the soil with Treflan $\left(4 \mathrm{dm}^{3} \cdot \mathrm{ha}^{-1}\right)$ before transplanting \\
\hline 05.22 & transplanting the plants into the field \\
\hline 06.02 & treating with NPK $\left(0.3 \%\right.$ Azofoska $1 \mathrm{dm}^{3}$ per plant) \\
\hline $06.06,06.09$ & $\begin{array}{l}\text { Betokson treatment of cvs. New Yorker and Venture plants, } \\
\text { respectively }\end{array}$ \\
\hline $06.13,19$ and 22 & treating the plants of both cultivars with Betokson \\
\hline 06.27 & repeated treatment with Betokson only for cv. Venture \\
\hline 06.07 & spraying with Dithane $0.2 \%$ and separately with Pirimor $0.05 \%$ \\
\hline 06.12 & mechanical cultivation \\
\hline 06.14 & spraying with herbicide Sencor $0.7 \mathrm{~kg} / \mathrm{ha}$ \\
\hline \multicolumn{2}{|c|}{$07.18,08.03$} \\
\hline $08.12,09.01$, and & \\
\hline 09.12 & Dithane $0.35 \%$ or $0.2 \%$ \\
\hline 07.31 & Pirimor $0.7 \%$ \\
\hline $09.06,09.13$ & Danicol (fungicide) $0.25 \%$ \\
\hline
\end{tabular}

For dates of picking see Fig. 1. 
$P$ in triple superphosphate and $175 \mathrm{~kg} \mathrm{~K}$ as technical nutrient $\mathrm{K}_{2} \mathrm{SO}_{4}$. For the dates of sowing, planting and other treatments, see Table 1.

The plants of 2 cultivars, New Yorker and Venture, were treated as follows:

- dipping the trusses in a solution of Betokson at concentrations of 2.5 $\mathrm{cm}^{3} \cdot \mathrm{dm}^{-3}$ or $5.0 \mathrm{~cm}^{3} \cdot \mathrm{dm}^{-3}$, which corresponds to 25 and $50 \mathrm{mg} \cdot \mathrm{dm}^{-3}$ of NOA; symbols of these treatments: NOA 25 (or 50) dip,

- spraying whole plants with Betokson at the same two concentrations, symbols: NOA 25 (or 50) spr.,

- spraying whole plants with $\mathrm{GA}_{3}$, in concentrations of $25 \mathrm{mg} \cdot \mathrm{dm}^{-3}$ or with a mixture of $\mathrm{GA}_{3}$ with Betokson, symbols: $\mathrm{GA}_{3} 25 \mathrm{spr}$. and $\mathrm{GA}_{3} 25+$ NOA spr.,

- spraying whole plants with pure NOA plus $0.04 \%$ Tween 20 , symbol: NOA $25+$ Tw. spr.; this was done in order to check if Tween as a surfactant is better than the surfactants used in Betokson,

- control plants sprayed only with distilled water.

In each case distilled water was used to dissolve the preparations or compounds to obtain the needed concentration.

After picking the fruits were divided into several quality grades, not strictly corresponding to the Polish commercial quality grades:

- 1st quality grade: $\geqslant 4 \mathrm{~cm}$ diameter. healthy. well-shaped.

- 2nd quality grade: 2-3.9 cm diameter, healthy, well-shaped, plus those $>2 \mathrm{~cm}$ diameter, with healed cracks,

- 3rd quality grade: diameter less than $2 \mathrm{~cm}$, healthy, well-shaped,

- misshapen fruits of all sizes,

- freshly cracked, cracks not healed, fruits of all sizes (no such fruits were, however, found in this year),

- diseased fruits of all sizes.

The yield was further divided into the following classes: "very early yield", "early yield" and "total yield" (see Figs. 1 and 2). The picking dates are shown in the figures. The marketable yield is the sum of the weights of the first two quality grades.

The experiment was set up in 4 randomized blocks (replications) in split-plot design: factor A - varieties: New Yorker and Venture, factor B - treatments - see Table 2. There were 20 plants on each plot.

The results were examined using method of variance analysis and Duncan's multiple range test for significance.

\section{RESULTS}

The very early yield was markedly increased by Betokson application in all methods of treatment: 4-11 times in cv. Venture plants and 3-4 times in those of cv. New Yorker plants. (Tables 2 and 3). The yield was greater when a higher 


\section{Table 2}

The influence of NOA (Betokson) and $\mathrm{GA}_{3}$ on the very early yield (first 4 pickings, for dates see Figs. 1 and 2) of cv. Venture. dip = dipping trusses, spr = spraying whole plants. Numbers in parentheses indicate how many times the yield of treated plants is larger than that of controls

\begin{tabular}{|c|c|c|c|c|c|c|}
\hline \multirow{2}{*}{$\begin{array}{l}\text { Growth regulator } \\
\text { and concentration } \\
\text { in } \mathrm{mg} \cdot \mathrm{dm}^{-3}\end{array}$} & \multirow{2}{*}{ Yield $\left(\mathrm{kg} \cdot 10 \mathrm{~m}^{-2}\right)$} & \multicolumn{3}{|c|}{$\begin{array}{c}\text { Quality grades* } \\
\text { (\% of yield-fresh wt.) }\end{array}$} & \multirow{2}{*}{$\begin{array}{l}\text { Misshapen } \\
\text { fruits (\% of } \\
\text { yield-fresh } \\
\text { wt.) }\end{array}$} & \multirow{2}{*}{$\begin{array}{c}\text { Diseased } \\
\text { fruits } \\
\text { (\% of yield- } \\
\text {-fresh weigh }\end{array}$} \\
\hline & & 1st & 2nd & 3rd & & \\
\hline 1. Controls & $1.43 \mathrm{a}^{* *}$ & 94.3 & 5.7 & 0 & 0 & 0 \\
\hline 2. NOA 25 dip & $5.93 \mathrm{bc}(4.1)$ & 85.8 & 10.8 & 0 & 1.7 & 1.7 \\
\hline 3. NOA 50 dip & $7.74 \mathrm{~cd}(5.4)$ & 83.2 & 14.9 & 0 & 0.9 & 1.0 \\
\hline 4. NOA $25 \mathrm{spr}$ & $10.67 \mathrm{~d}(7.5)$ & 85.0 & 13.0 & 0 & 1.4 & 0.6 \\
\hline 5. NOA $50 \mathrm{spr}$ & 15.09 e $(10.6)$ & 81.0 & 17.1 & 0 & 1.2 & 0.5 \\
\hline 6. NOA $25, \mathrm{Tw}$ spr & $7.46 \mathrm{~cd}(5.2)$ & 86.2 & 12.1 & 0 & 1.7 & 0 \\
\hline 7. NOA $25, G_{3} 25$ & $10.10 \mathrm{~d}(7.1)$ & 87.1 & 11.2 & 0 & 0.3 & 1.4 \\
\hline 8. $\mathrm{GA}_{3} 25 \mathrm{spr}$ & $3.89 \mathrm{ab}(2.7)$ & 75.1 & 21.8 & 0 & 2.1 & 1.0 \\
\hline
\end{tabular}

* The quality grades do not correspond exactly to the Polish commercial quality grades (see Methods).

** Numbers marked with the same letter do not differ significantly from each other.

Table 3

The influence of Betokson and $\mathrm{GA}_{3}$ on the very early yield (first 4 pickings) cv. New Yorker. For other details see Table 2

\begin{tabular}{|c|c|c|c|c|c|c|}
\hline \multirow{2}{*}{ Treatment } & \multirow{2}{*}{ Yield $\left(\mathrm{kg} \cdot 10 \mathrm{~m}^{-2}\right)$} & \multicolumn{3}{|c|}{$\begin{array}{l}\text { Quality grades } \\
\text { (\% of yield-fresh wt.) }\end{array}$} & \multirow{2}{*}{$\begin{array}{l}\text { Misshapen } \\
\text { fruits (\% of } \\
\text { yield-fresh } \\
\text { wt.) }\end{array}$} & \multirow{2}{*}{$\begin{array}{l}\text { Diseased } \\
\text { fruits } \\
\text { (\% of yield- } \\
\text {-fresh wt. }\end{array}$} \\
\hline & & $1 \mathrm{st}$ & 2nd & $3 \mathrm{rd}$ & & \\
\hline 1. Controls & $4.82 \mathrm{a}$ & 87.6 & 8.5 & 0 & 2.3 & 1.6 \\
\hline 2. NOA $25 \mathrm{dip}$ & $12.05 \mathrm{~b}(2.8)$ & 90.7 & 6.9 & 0 & 1.2 & 1.2 \\
\hline 3. NOA 50 dip & $13.57 \mathrm{~d}(3.2)$ & 86.9 & 10.1 & 0 & 2.4 & 0.6 \\
\hline 4. NOA $25 \mathrm{spr}$ & $12.00 \mathrm{~b}(2.8)$ & 86.5 & 9.8 & 0 & 2.7 & 1.0 \\
\hline 5. NOA $50 \mathrm{spr}$ & $17.68 \mathrm{c}(4.1)$ & 87.5 & 7.0 & 0 & 4.9 & 0.6 \\
\hline $\begin{array}{l}\text { 6. NOA } 25, \mathrm{Tw}, \mathrm{spr} \\
\text { 7. NOA } 25, \mathrm{GA}_{3}\end{array}$ & $12.62 \mathrm{~b}(2.9)$ & 86.8 & 9.8 & 0 & 2.9 & 9.5 \\
\hline $25 \mathrm{spr}$ & 17.09 c (4.0) & 86.6 & 7.5 & 0.1 & 3.5 & 2.3 \\
\hline 8. $\mathrm{GA}_{3} 25 \mathrm{spr}$ & 6.32 a (1.4) & 80.5 & 13.8 & 0.6 & 2.7 & 2.4 \\
\hline
\end{tabular}

Betokson concentration was used. Spraying the whole plant increased the very early yield, in most cases, more than dipping the trusses. Gibberellic acid alone did not significantly increase the crop. NOA combined with $\mathrm{GA}_{3}$ increased the crop more than NOA alone only in cv. New Yorker plants. Treatments containing $\mathrm{GA}_{3}$ caused drastic and persistent chlorosis of leaves.

In all treatments and in control plants, the precentage of first quality grade fruits was high $(75-94 \%)$. There were almost no fruits of the 3 rd quality grade 
in the very early yield of both varieties. Also, the precentage of misshapen and diseased fruits was very low (Tables 2 and 3).

The early yield (which also included "very early yield") was in the NOA treated cv. Venture plants, about 2.7-3.6 times higher than in controls (Table 4). The differences among particular NOA treatments were, in most cases, not significant, however, the effect of higher concentrations was stronger. In cv. New Yorker, the early yield was similar in control and treated plants (Table 5).

\section{Table 4}

The influence of Betokson and $\mathrm{GA}_{3}$ on the early yield (first 8 pickings) of cv. Venture. For other details see Table 2

\begin{tabular}{|c|c|c|c|c|c|c|}
\hline \multirow{2}{*}{ Treatment } & \multirow{2}{*}{ Yield $\left(\mathrm{kg} \cdot 10 \mathrm{~m}^{-2}\right)$} & \multicolumn{3}{|c|}{$\begin{array}{l}\text { Quality grades } \\
(\% \text { of yield-fresh wt.) }\end{array}$} & \multirow{2}{*}{$\begin{array}{l}\text { Misshapen } \\
\text { fruits }(\% \text { of } \\
\text { yield-fresh } \\
\text { wt.) }\end{array}$} & \multirow{2}{*}{$\begin{array}{l}\text { Diseased } \\
\text { fruits } \\
\text { (\% of yield- } \\
\text {-fresh wt.) }\end{array}$} \\
\hline & & $1 \mathrm{st}$ & 2nd & 3 rd & & \\
\hline 1. Controls & $7.62 \mathrm{a}$ & 91.5 & 5.8 & 0.4 & 2.3 & 0 \\
\hline 2. NOA 25 dip & $22.75 \mathrm{~b} \quad(3.0)$ & 89.0 & 9.0 & 0 & 1.4 & 0.6 \\
\hline 3. NOA 50 dip & 23.49 bc (3.1) & 88.5 & 10.6 & 0 & 0.3 & 0.6 \\
\hline 4. NOA $25 \mathrm{spr}$ & $22.28 \mathrm{~b} \quad(2.9)$ & 86.8 & 10.9 & 0.1 & 0.8 & 1.4 \\
\hline 5. NOA $50 \mathrm{spr}$ & $27.47 \mathrm{c},(3.6)$ & 84.9 & 13.6 & 0 & 0.9 & 0.5 \\
\hline $\begin{array}{l}\text { 6. NOA } 25, \mathrm{Tw}, \mathrm{spr} \\
\text { 7. NOA } 25, \mathrm{GA}_{3}\end{array}$ & 20.79 b $\quad(2.7)$ & 84.8 & 13.6 & 0.1 & 1.1 & 0.4 \\
\hline $25 \mathrm{spr}$ & $20.53 \mathrm{~b} \quad(2.7)$ & 89.1 & 8.7 & 0.1 & 0.9 & 1.2 \\
\hline 8. $\mathrm{GA}_{3} 25 \mathrm{spr}$ & $19.73 \mathrm{~b} \quad(2.6)$ & 88.4 & 10.4 & 0.4 & 0.5 & 0.3 \\
\hline
\end{tabular}

Table 5

The influence of Betokson and $\mathrm{GA}_{3}$ on the early yield (first 8 pickings) of cv. New Yorker. For other details see Table 2

\begin{tabular}{|c|c|c|c|c|c|c|}
\hline \multirow{2}{*}{ Treatment } & \multirow{2}{*}{ Yield(kg $\left.10 \mathrm{~m}^{-2}\right)$} & \multicolumn{3}{|c|}{$\begin{array}{l}\text { Quality grades } \\
\text { (\% of yield-fresh wt.) }\end{array}$} & \multirow{2}{*}{$\begin{array}{l}\text { Misshapen } \\
\text { fruits ( } \% \text { of } \\
\text { yield-fresh } \\
\text { wt.) }\end{array}$} & \multirow{2}{*}{$\begin{array}{l}\text { Diseased } \\
\text { fruits } \\
\text { (\% of yield- } \\
\text {-fresh wt.) }\end{array}$} \\
\hline & & $1 \mathrm{st}$ & 2nd & 3 rd & & \\
\hline 1. Controls & $18.15 \mathrm{a}$ & 91.3 & 6.8 & 0 & 1.2 & 0.7 \\
\hline 2. NOA $25 \mathrm{dip}$ & $22.30 \mathrm{ab}$ & 91.1 & 5.3 & 0 & 2.4 & 1.2 \\
\hline 3. NOA $50 \mathrm{dip}$ & $20.03 \mathrm{ab}$ & 88.4 & 8.8 & 0 & 2.2 & 0.6 \\
\hline 4. NOA $25 \mathrm{spr}$ & $17.87 \mathrm{a}$ & 87.5 & 9.4 & 0 & 2.4 & 0.7 \\
\hline 5. NOA $50 \mathrm{spr}$ & $19.99 \mathrm{ab}$ & 88.2 & 6.8 & 0 & 4.4 & 0.6 \\
\hline $\begin{array}{l}\text { 6. NOA } 25, \mathrm{Tw}, \mathrm{spr} \\
\text { 7. NOA } 25, \mathrm{GA}_{3}\end{array}$ & $24.66 \mathrm{~b}$ & 89.8 & 7.4 & 0.1 & 2.2 & 0.5 \\
\hline $25 \mathrm{spr}$ & $22.05 \mathrm{ab}$ & 85.8 & 8.7 & 0.4 & 3.1 & 2.0 \\
\hline 8. $\mathrm{GA}_{3} 25 \mathrm{spr}$ & $17.94 \mathrm{a}$ & 84.1 & 12.0 & 0.9 & 1.5 & 1.5 \\
\hline
\end{tabular}


The only significant difference was between "pure NOA plus Tween"-treated plants and the controls. In both cultivars, the percentage of misshapen, diseased and 3rd quality grade fruits was very low in this yield (Tables 4 and 5).

The total yield of plants treated with NOA by dipping the trusses was, in most cases, similar to that of control plants, especially when a lower concentration of this preparation was used (Tables 6 and 7). The method of spraying the whole plant with NOA caused a decrease of the total yield. GA alone, or in combination with NOA, markedly lowered the total yield of both cultivars (Figs. 1 and 2).

\section{Table 6}

The influence of Betokson and $\mathrm{GA}_{3}$ on the total yield of cv. Venture. For other details see Table 2

\begin{tabular}{|c|c|c|c|c|c|c|c|}
\hline \multirow{2}{*}{ Treatment } & \multirow{2}{*}{$\begin{array}{c}\text { Total } \\
\text { yield } \\
\left(\mathrm{kg} \cdot 10 \mathrm{~m}^{-2}\right)\end{array}$} & \multicolumn{3}{|c|}{$\begin{array}{c}\text { Quality grades } \\
(\% \text { of yield-fresh wt. })\end{array}$} & \multirow{2}{*}{$\begin{array}{l}\text { Misshapen } \\
\text { fruits }(\% \text { of } \\
\text { yield-fresh } \\
\text { wt.) }\end{array}$} & \multirow{2}{*}{$\begin{array}{l}\text { Diseased } \\
\text { fruits } \\
\text { (\% of yield- } \\
\text {-fresh wt.) }\end{array}$} & \multirow{2}{*}{$\begin{array}{c}\text { Marketable } \\
\text { yield } \\
\left(\mathrm{kg} \cdot 10 \mathrm{~m}^{-2}\right)\end{array}$} \\
\hline & & $1 \mathrm{st}$ & 2nd & $3 \mathrm{rd}$ & & & \\
\hline Controls & $67.36 \mathrm{c}$ & 26.5 & 6.1 & 0.1 & 0.2 & 67.1 & $22.01 \mathrm{a}$ \\
\hline 2. NOA $25 \mathrm{dip}$ & $69.60 \mathrm{c}$ & 42.7 & 9.2 & 0 & 0.4 & 47.7 & $36.12 \mathrm{~b}$ \\
\hline 3. NOA 50 dip & $61.05 \mathrm{c}$ & 48.6 & 10.0 & 0 & 0.1 & 41.3 & $35.91 \mathrm{~b}$ \\
\hline 4. NOA $25 \mathrm{spr}$ & $50.58 \mathrm{~b}$ & 51.1 & 11.3 & 0.1 & 0.3 & 37.2 & $31.52 \mathrm{~b}$ \\
\hline 5. NOA $50 \mathrm{spr}$ & $48.00 \mathrm{~b}$ & 54.7 & 13.7 & 0 & 0.5 & 31.0 & $32.29 \mathrm{~b}$ \\
\hline 6. NOA $25, \mathrm{Tw}, \mathrm{spr}$ & $62.33 \mathrm{c}$ & 40.6 & 9.9 & 0.1 & 0.4 & 49.0 & $31.53 \mathrm{~b}$ \\
\hline $25 \mathrm{spr}$ & 34.94 a & 58.6 & 6.8 & 0.1 & 0.5 & 34.0 & $22.86 \mathrm{a}$ \\
\hline 3. $\mathrm{GA}_{3} 25 \mathrm{spr}$ & 37.15 a & 53.8 & 8.4 & 0.3 & 0.3 & 37.2 & $23.14 \mathrm{a}$ \\
\hline
\end{tabular}

Table 7

The influence of Betokson and $\mathrm{GA}_{3}$ on the total yield of cv. New Yorker. For other details see Table 2

\begin{tabular}{|c|c|c|c|c|c|c|c|}
\hline \multirow{2}{*}{ Treatment } & \multirow{2}{*}{$\begin{array}{c}\text { Total } \\
\text { yield } \\
\left(\mathrm{kg} \cdot 10 \mathrm{~m}^{-2}\right)\end{array}$} & \multicolumn{3}{|c|}{$\begin{array}{c}\text { Quality grades } \\
\text { ( } \% \text { of yield-fresh wt.) }\end{array}$} & \multirow{2}{*}{$\begin{array}{l}\text { Misshapen } \\
\text { fruits (\% of } \\
\text { yield-fresh? } \\
\text { wt.) }\end{array}$} & \multirow{2}{*}{$\begin{array}{l}\text { Diseased } \\
\text { fruits } \\
1 \% \text { of yield- } \\
\text {-fresh wt.) }\end{array}$} & \multirow{2}{*}{$\begin{array}{c}\text { Marketable } \\
\text { yield } \\
\left(\mathrm{kg} \cdot 10 \mathrm{~m}^{-2}\right)\end{array}$} \\
\hline & & 1 st & 2nd & $3 \mathrm{rd}$ & & & \\
\hline 1. Controls & $58.68 \mathrm{e}$ & 40.4 & 10.4 & 0.20 & 0.4 & 48.6 & $29.85 \mathrm{c}$ \\
\hline 2. NOA $25 \mathrm{dip}$ & $53.48 \mathrm{de}$ & 46.1 & 12.1 & 0.1 & 1.0 & 40.7 & $29.17 \mathrm{c}$ \\
\hline 3. NOA 50 dip & $46.06 \mathrm{~cd}$ & 46.9 & 11.9 & 0.2 & 1.0 & 40.0 & $27.12 b c$ \\
\hline 4. NOA $25 \mathrm{spr}$ & $39.05 \mathrm{bc}$ & 45.5 & 13.5 & 0.2 & 1.1 & 39.7 & $23.01 \mathrm{ab}$ \\
\hline 5. NOA $50 \mathrm{spr}$ & $29.39 \mathrm{ab}$ & 63.5 & 8.5 & 0 & 3.0 & 25.0 & $21.27 \mathrm{a}$ \\
\hline $\begin{array}{l}\text { 6. NOA } 25, \mathrm{Tw}, \mathrm{spr} \\
\text { 7. NOA } 25, \mathrm{GA}_{3}\end{array}$ & $50.27 \mathrm{de}$ & 48.2 & 8.4 & 0.1 & 1.1 & 42.2 & $28.46 \mathrm{c}$ \\
\hline $25 \mathrm{spr}$ & $27.94 \mathrm{a}$ & 69.5 & 8.2 & 0.7 & 2.5 & 19.1 & $21.67 \mathrm{a}$ \\
\hline 8. $\mathrm{GA}_{3} 25 \mathrm{spr}$ & $24.84 \mathrm{a}$ & 67.7 & 13.0 & 1.3 & 1.1 & 16.9 & $20.02 \mathrm{a}$ \\
\hline
\end{tabular}




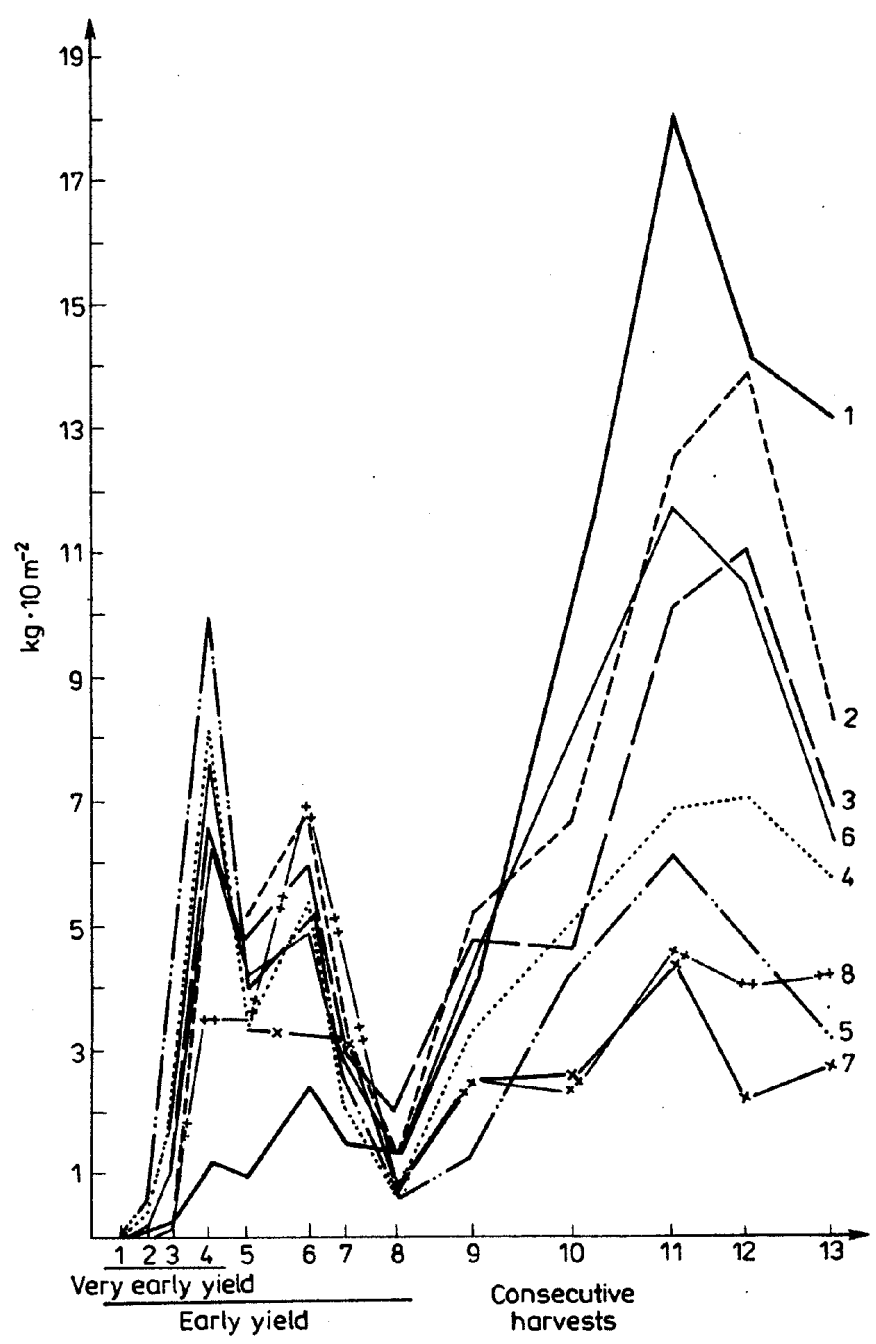

Fig. 1. The dynamics of yielding of tomato plants cv. Venture. The treatments (concentrations in $\mathrm{mg} \cdot \mathrm{dm}^{-3}$, dip - dipping the trusses, spr - spraying whole plants): 1 - Controls, 2 - NOA 25 dip, 3 - NOA 50 dip, 4 - NOA 25 spr, 5 - NOA 50 spr, 6 - NOA 25 + Tw spr, 7 - NOA $25+\mathrm{GA}_{3} 25 \mathrm{spr}, 8-\mathrm{GA}_{3} 25 \mathrm{spr}$. In all treatments except 6, NOA was used in the form of the preparation Betokson of Polish production. In treatment 6 crystalline NOA was applied. For dates of harvest see Figure 2

The percentages of 3rd quality grade and of misshapen fruit were very low in the total yield, whereas the percentage of diseased fruits was high (Tables 6 and 7). These percentages were the highest in control plants. The late tomatoes were heavily infected by Phytophthora infestans. Due to this fact, the total marketable crop was in the NOA-treated cv. Venture plants higher than in control ones (Table 6). Cv. New Yorker plants sprayed with NOA showed 


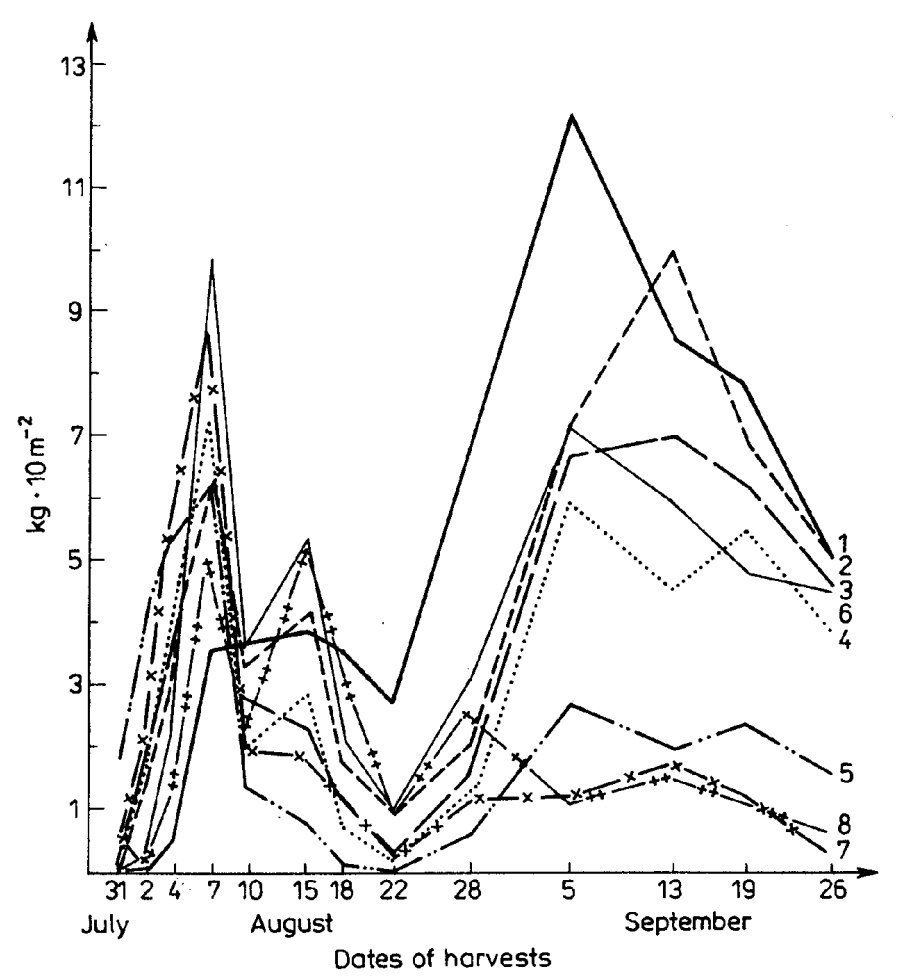

Fig. 2. The dynamics of yielding of tomato plants cv. New Yorker. For other detalis see Figure 1

a less total marketable crop than controls, except for treatment with Tween 20 (Table 7).

Thus the spraying of the whole plant caused, in most cases, a greater increase of the early yield than dipping the clusters, but concomitantly caused a greater decrease of the late yield. The economic effect depends on the cultivar and on the incidence of Phytophthora infestans and other autumnal diseases of tomato.

\section{DISCUSSION}

Auxins were first applied to improve fruit set in tomato by Gustafs on (1937). NOA was recognized early as a good compound for this purpose (Gustafson, 1942). Presently NOA is an active ingredient of many commercial preparations used for stimulating tomato fruit set in protected cultivation (Lipari, 1979; Ruggeri and Mauromicale, 1979). Recently bendroquinone, a naphthoquinone derivative (2-benzimidoyl-3-hydroxy-1,4 naphthoquinone), was tried by spraying the whole plant (Yukinaga et al., 1980). Besides that, phenoxy compounds like 4-chlorophenoxyacetic acid (4-CPA), and 
orthochlorophenoxypropionic acid (CPPA) are commonly included as active ingredients of the commercial parthenocarpy-stimulating preparations used in protected cultivation (Ruggeri and Mauromicale, 1979; Lipari, 1979, 1982). Rarely was 2,4-dichlorophenoxyacetic acid (2,4D) used for this purpose (Glukhenki, 1968) as well as n-metatolilphtalamic acid (MNTP) (Lipari and Mauromicale, 1979) or morphactin (Lukasik and Huszcza, 1974). In Poland only NOA is used in practice. There are numerous articles and papers elucidating different aspects of its use in protected cultivation (Borkowski, 1970; K ę pk owa, 1962; Les ki, 1963). In all these articles and papers (see also Kępkowa, 1955, 1959, 1968; Kępka, 1966; Kępkowa and Legut, 1960-1961; Kępkowa and Rutkowska, 1960-1961) it was advised that Betokson be used as trusses dip or spray. Precautions were issued against using it on whole plants. Trusses dips or sprays were also recommended by other authors (Lipari and Mauromicale, 1979; Ruggeri and Mauromicale, 1979). There is only one preparation among the 28 cited by these authors for which the possibility of using it as a whole-plant-spray is mentioned (preparation Sendlene in conc. $175 \mathrm{mg} / \mathrm{l}$, based on NOA and its derivatives).

In large scale, out-door tomato production, the auxin treatment by dipping or spraying the trusses is costly. Our earlier results (Górecka and Jankiewicz, 1978), and those presented in this paper, show that NOA applied on the whole plant often increases the very early yield more than the treatment of trusses only.

In the year when this experiment was done the effect of NOA was especially marked due to a cold summer, unfavourable for the fruit set in tomato (compare Kepk owa, 1955, 1962). Cool and wet weather occurring during the second part of the summer also caused a heavy attack of Phytophthora infestans. In such circumstances, Betokson, irrespective of the method of treatment, augmented the percentage of healthy fruits in the total crop by increasing the share of the early crop in the total yield.

Spraying the whole plant stimulated the very early and early yield sometimes more than cluster-dip (see also Góreck a and Jankiewicz, 1978), however, the total yield was always lower with whole-plant spray. Emmert (1961), applying NOA on the whole plant in open ground, observed that a decrease of the total yield could be partly prevented when boron was added to the treatment. Our preliminary observation did not confirm these results.

There may be two mechanisms by which the whole-plant-spray with NOA lowers the total yield:

1. NOA directly inhibits the development of the young parts formed in the apex (es) including very young trusses;

2. NOA increases the fruit-set in the first trusses and stimulates the development of the early fruits. However, these fruits competitively inhibit the growth of the later-formed ones in the untreated trusses (Li pari 1986; St a rck et al., 1987). They also competitively inhibit the apexes causing the treated 
plants to be smaller (Borkowski and Jankiewicz, 1980), with less trusses for late cropping.

Litwińska (1955) and Kępkowa (1955), who applied Betokson on non-protected tomato by dipping the trusses, encountered a variability of results, depending on the year. This is conceivable since the temperature influences the sensitivity of flowers to growth regulators (Kinet, 1985) as well as pollination and fruit development (K e p k ow a, 1955, 1968). Similar variability occurred when the whole-plant-spray was applied (compare the resuls of this experiment with the earlier ones of Góreck a and Ja nkiewicz, 1978). In both years, however, the very early yield was augmented. Since the price for early tomatoes is much higher than that for later ones, the application of NOA for non-protected tomatoes is worth further trials.

Gibberellic acid has rarely been used for tomato fruit-set stimulation (Younis and El-Tigani, 1977; Verlodt and Boesman, 1974), although its ability to evoke parthenocarpy in tomato and other species is well konwn (see Muromtsev and Agnistik ova, 1973; Bangerth and Sjut, 1977; Kinet, 1985). In our experiment, $\mathrm{GA}_{3}$ was shown to be unsuitable for application on whole plants. These results corroborate the earlier ones of Borkowski (1960-1961). Strong chlorosis of tomato leaves due to GA treatment, however, was not observed by him, but was observed by Hayashi (1961) in a field experiment if the fertilizer supply was insufficient. Although $\mathrm{GA}_{3}$ treatment seems unsuitable for whole-plant-spray of tomato, it was to be beneficial in combination with NOA for treatment of trusses in protected cultivation (Strack, 1986; Starck and Stahl, 1986; Strack et al., 1987).

\section{REFERENCES}

Abad M., Guardiola J. L., 1986. Fruit-set and development in the tomato (Lycopersicon esculentum Mill.) grown under protected condition during the cool season in the South-Eastern coast region of Spain. The response to exogenous growth regulators. Acta Hort. 191: 123-32.

Bangerth F., Sjut V., 1977. Induced parthenocarpy - a tool for investigating hormone regulated physiological processes in fruits. Acta Hort. 80: 169-174.

Borkowski J., 1960-1961. Wyniki doświadczeń nad zastosowaniem gibereliny na pomidory, groch i kalarepe. Biul. Warz. 5: 45-56.

Bork owski J., 1970. Kiedy hormonizacja pomidorów daje dobre rezultaty. Hasło Ogrodn. Roln. 11: $330-31$.

Bork owski J., Jankiewicz L. S., 1980. Effect of chlormequat chloride, auxin $\beta$-naphthoxyacetic acid and ethephon on early and total yield of tomato in open field. Acta Agrobot. 36: 17-25.

Emmert E. H., 1961. Effect of boron, dextrose and beta-naphthoxyacetic acid on fertilizer requirements and yields and fruit quality of tomatoes. Proc. Amer. Soc. Hort. Sci. 77: 495-99.

Glukhenki G. N., 1968. O priiomakh uskoreniya i povysheniya urozhaya tomatov $v$ otkrytom grunte. Fiziol. Rast. 15: 1086-1088.

Górecka K., Jankiewicz L. S., 1978. Khimicheskoe regulirovanie zavyazyvaniya polodov tomatov i ikh rosta i sozrevaniya. Primenene Regulyatorov Rosta. Mezhdunarodnyj Simpozium v Rostoke 1978. 
Gustafs on F. G., 1937. Inducement of fruit development by growth promoting chemicals. Proc. Nat. Acad. Sci. 22: 628-38.

Gustafs on F. G., 1942. Beta-naphthoxyacetic acid as an inductor of parthenocarpy in tomatoes. Proc. Amer. Soc. Hort. Sci. 40: 387-9.

Hayashi T., 1961. The effect of gibberellin treatment on the photosynthetic actitivity of plants. [In:] Plant Growth Regulation (4th Int. Conf. on Plant Growth Regulation), The Iowa State University Press, Ames, pp. 579-587.

Kępka A. K., 1966. The use of auxin sprays or artificial pollination in order to improve fruit setting of tomatoes grown under glass. Acta Hort. 4: 55-62.

Kępkowa A., 1955. Wpływ temperatury na efekt hormonizacji pomidorów szklarniowych. Biul. Warz. 3: 195-202.

Kępk owa A., 1959. Efekt kilku różnych związków chemicznych i preparatów zastosowanych do hormonizowania pomidorów szklarniowych i wczesnych gruntowych. Biul. Warz. 4: 305-326.

Kępkowa A., 1962. Hormonizacja pomidorów gruntowych. Owoce, Warzywa, Kwiaty, 10: 7-9.

Kępkowa A., 1968. Wpływ hormonizacji na zawiązywanie i wzrost owoców oraz plon pomidorów szklarniowych. Praca hab. SGGW, Warszawa.

Kępkowa A., Legut L., 1960-61. Wartość produkcji szklarniowej różnych odmian pomidorów heterozyjnych i standardowych - hormonizowanych i niehormonizowanych. Biul. Warz. 5: 251-262.

Kępkowa A., Rutkowska Z., 1960-61. Wpływ sztucznego zapylania i hormonizacji na plon pomidorów szklarniowych. Biul. Warz. 5: 267-76.

Kinet J. M., 1985. Controle du development de l'inflorescence de la tomate par les facteurs de l'environement et les régulateurs de croissance. Revue Horticole, 260: 30-36.

Leski B. 1963. Hormonizacja pomidorów Betoksonem z dodatkiem mikroelementów. Owoce, Warzywa, Kwiaty, 9: 10-11.

Lipari V., 1979. Effect of auxin substances distributed in different concentrations on tomato yield in protected cultivation. Riv. Ortoflorofrutt. It. 63: 215-44.

Lipari V., 1982. Results of research on the application technique of auxinic growth-regulators to tomato in protected cultivation. Riv. Ortoflorofrutt. It. 66: 59-73.

Lipari V., 1986. Effects of auxin on competition between trusses of the tomato plant. Acta Hort. 191: 171-78.

Lipari V., Mauromicale G., 1979. Degree of efficacy of auxin substances on tomato fructification in greenhouse in relation to distribution technique and minimum temperature level. Riv. Ortoflorofrutt. It. 63: 245-66.

Litwińska J., 1955. Wpływ sposobu hormonizacji na wczesność i wysokość plonu pomidorów gruntowych. Biul. Warz. 3: 84-89.

Lukasik S., Huszcza W., 1974. Effect of morphactin IT 3456 (methyl-2-chloro-9-hydroxyfluorene-(9)-carboxylate) on parthenocarpic fruit development of tomatoes. Acta Agrobot. 27: $71-80$.

Muromtsev G. S., Agnistikova W. N., 1973. Gormony rastenij gibberelliny. Izdat. Nauka, Moskva.

Ruggeri A. Mauromicale G., 1979. Auxins in the fruit setting process of the tomato and characteristics of relative commercial products. Riv. Ortoflorofrutt. It. 63: 201-214.

Starck Z., 1986. Nowa metoda hormonizowania pomidorów szklarniowych. Owoce, Warzywa, Kwiaty, 15 (4): 6.

Starck Z., Stahl E., 1986. Effect of fruit growth on the photosynthesis and remobilization of assimilates. [In:] Regulation of photosynthesis in fruit trees. A. N. Laks, F. Lenz (eds.). Symp. Proc. Publ. Agr Exp. Sta., Geneva N. Y.

Starck Z., Stahl E., Witek-Czupryńska B., 1987. Competitive ability of clusters in tomato plants with source-sink relation modulated by irradiation and exogenous growth regulators. Acta Physiol. Plant. 9: 89-99.

Verlodt M., Boesman G., 1974. Influence de quelques techniques culturales et de l'acide 
gibberellique sur la précocité, la qualite, et le rendement de quelques varietés de tomatoes. Meded. Fac. Landbouwwettenschappen, Rijksuniv. Gent. 39: 192-209.

Younis M. E., El-Tigani S., 1977. Comparative effects of growth substances on the growth, flowering and fruiting of tomato plants. Acta Agron. Sci. Hung. 26: 89-103.

Yukinaga H., Hirabayashi M., Miki N., Sakaguchi C., 1980. The effect of the naphthoquinone derivative 2-benzimidoyl-3-hydro-1,4 naphthoquinone on the growth of tomato. II. The effect of partial and whole-plant sprays. Jour. Japan. Soc. Hort. Sci. 48: 459-67.

\section{Zwiększenie plonu wczesnego pomidorów (Lycopersicon esculentum Mill.) w odkrytym gruncie za pomocą oprysków całych roślin kwasem naftoksy- octowym}

\section{Streszczenie}

Preparat powodujący partenokarpię - Betokson - zawierający kwas 2-naftoksyoctowy (NOA) jako składnik czynny zastosowano w oprysku na całe rośliny. Jako jedną $z$ kombinacji kontrolnych zastosowano zanurzanie gron $w$ roztworze NOA (technika zalecana dotychczas). NOA stosowany każdym z tych dwu sposobów zwiększał plon bardzo wczesny (pierwsze 4 zbiory) 4-11 razy u odmiany Venture i 3-4 razy u odmiany New Yorker, w porównaniu do plonu roślin kontrolnych nie traktowanych. Traktowanie całych roślin zwiększało wczesny plon bardziej niż zanurzanie gron. Również plon wczesny (pierwsze 8 zbiorów) zwiększyl się dzięki zastosowaniu NOA za pomocą obu metod traktowania $u$ odmiany Venture. U odmiany New Yorker zwiększenia tego jednak nie obserwowano. Traktowanie NOA zmniejszało plon późny. To zmniejszenie było silniejsze, gdy stosowano wyższe stężenie NOA oraz gdy stosowano opryskiwanie całych roślin. Kwas giberelinowy $\left(\mathrm{GA}_{3}\right)$ zastosowany sam, w oprysku na całe rośliny w stężeniu $25 \mathrm{mg} \cdot \mathrm{dm}^{-3}$ nie zwiększył plonu bardzo wczesnego, lecz $\mathrm{w}$ kombinacji z NOA zwiększył plon wczesny w odmianie New Yorker. GA $\mathrm{G}_{3}$ sam lub w kombinacji z NOA powodował znaczną chlorozę liści i znaczny spadek plonu ogólnego.

Wyniki te nie wystarczają jeszcze, aby dawać wskazówki praktyczne. 